\title{
Exploring the Links between Community-based Governance and Sustainable Energy use: Quantitative Evidence from Flanders
}

Thomas Bauwens and Nick Eyre

Thomas Bauwens ${ }^{1}$, School of Geography and The Environment, University of Oxford. Professional address: Oxford University Centre for the Environment, South Parks Road, Oxford, OX1 3QY, UK. Permanent address: Laboratory for Human-Environment Relations in Urban Systems (HERUS), École Polytechnique Fédérale de Lausanne. Station 2, Lausanne 1015, Switzerland.

Nick Eyre, School of Geography and The Environment, University of Oxford. Professional address: Oxford University Centre for the Environment, South Parks Road, Oxford, OX1 3QY, UK.

This paper is an author post-print version of a paper published with the journal Ecological Economics.

Please cite as follows:

Bauwens, T., Eyre, N. (2017). Exploring the links between community-based governance and sustainable energy use: Quantitative evidence from Flanders. Ecological Economics, 137, 163172. doi:10.1016/j.ecolecon.2017.03.006

The publisher's version can be found here.

${ }^{1}$ Corresponding author. 


\title{
Exploring the Links between Community-based Governance and Sustainable Energy use: Quantitative Evidence from Flanders
}

\author{
Thomas Bauwens and Nick Eyre
}

\begin{abstract}
:
Community-based energy organizations have been said to influence their members' energy-related behavior by activating social norms and by providing trustworthy information about sustainable energy investments and behaviors. However, little is known yet about members' actual energy use and how it differs from that of individuals who do not participate in such projects. In particular, selection effects are likely to arise, i.e. community-based energy projects may attract people that are different from the underlying population in terms of energy use. This article empirically addresses the question of the selection into community-based energy projects in terms of energy use, focusing on the case of renewable energy cooperatives. Based on quantitative data from an original survey conducted with one renewable energy cooperative in Flanders and using probit regression analyses, it contrasts a sample of cooperative members with an appropriate comparison group in terms of electricity usage. The results show that electricity consumption is positively related with cooperative membership, suggesting that high use consumers have greater incentives to join a communitybased organization which provides assistance and advice on the adoption of green technologies and energy efficiency measures. These findings contribute to an understanding of the relationship between community-based governance and sustainable energy practices.
\end{abstract}

Keywords: community, renewable energy cooperative, electricity consumption, selection process, Flanders. 


\section{Introduction}

Climate change associated with the emission of greenhouse gases (GHGs) is among the most crucial challenges of the twenty-first century. Averting massive climate change is a global public good, because everyone benefits from reduced GHG emissions even if they do not contribute any effort themselves, and therefore requires collective action (Sandler, 2004). To tackle this issue, many analysts call for an institutional solution at the global level, because global threats such as climate change are believed to require 'global solutions' negotiated internationally (Nordhaus, 1994; Stavins, 1997; Stern, 2007; Wiener, 2007). However, a binding and enforced agreement including all principal emitters and targeting an ambitious decrease in global GHG emissions will take long to develop (Ostrom, 2010), despite promising commitments at the $21^{\text {st }}$ Conference of the Parties held in Paris in Dec. 2015. Most governments' reluctance to engage in coordinated international policies bears out the conventional theory of collective action according to which rational agents pursuing their own interest will not participate in collective efforts because they have incentives to free-ride on the constructive behavior of others (Hardin, 1968; Olson, 1965).

More recently, various authors, spearheaded by Nobel Prize co-winner Elinor Ostrom, have challenged this 'zero contribution thesis' (Ostrom, 2000). They show that, under certain conditions, agents involved in a collective-action problem have self-organizational capabilities and are able to implement institutional arrangements in order to solve it in the absence of external interventions (Ostrom, 1990). In particular, collective-action problems faced by large groups, such as climate change mitigation, are often decomposable into dilemmas at a smaller scale, some of which are typically surmountable given the existence of social norms and, especially, of pre-existing trust networks (e.g. Carattini et al., 2015; Cole, 2015). Given the lack of progress in global climate change negotiations, an increasing number of scholars have proposed that a global policy is not the only strategy needed but that actions are required at multiple, smaller scales to start the process of climate change mitigation (Bulkeley and Betsill, 2005; Bulkeley and Kern, 2006; Ostrom, 2012). 
Accordingly, several studies have argued that community-based energy (CBE) organizations facilitate collective action for climate change mitigation by fostering individual behavioral change toward more sustainable energy practices (Heiskanen et al., 2010; Middlemiss, 2011, 2008; Seyfang, 2010). CBE projects refer to formal or informal citizen-led initiatives which propose collaborative solutions, typically on a local basis, to facilitate the development of sustainable energy technologies and practices (Bauwens et al., 2016; Walker and Devine-Wright, 2007). In line with the contributions of Elinor Ostrom and other institutional scholars, CBE initiatives are said to influence their members' energy-related behavior by activating social norms and by providing trustworthy information about sustainable energy investments and behaviors. Fruitful as these lines of inquiry are, they have mainly relied on qualitative descriptions of the ways through which CBE projects can influence their members' behaviors. Little is known yet about their actual energy use and how it differs from that of individuals who do not participate in such projects. In particular, these studies do not deal with the selection effects that are likely to arise, i.e. CBE projects may attract people that are different from the underlying population in terms of energy use.

The present article seeks to contribute to fill this gap and addresses the question of the selection into $\mathrm{CBE}$ projects by empirically analyzing the electricity consumption of members of renewable energy cooperatives and contrasting it with that of an appropriate comparison group. More precisely, the research question addressed can be formulated as follows: are members of community-based energy projects different from the underlying population in terms of energy use and, if so, how? Note that we do not analyze how joining CBE organizations affects energy use, due to the observational nature of our data.

Our paper uses the case of renewable energy (RE) cooperatives, which constitute a specific type of CBE initiatives. The quantitative analysis performed is based on an original survey conducted among the members of one RE cooperative, Ecopower, located in Flanders, in the northern part of Belgium. In addition, this sample of cooperative members is contrasted with a sample of 
individuals sharing socio-demographic characteristics but not belonging to any RE cooperative. A probit regression model is used to examine the effect of electricity usage on the likelihood to join a RE cooperative. Following Brounen et al. (2012) and Ohler and Billger (2014), the model controls for socio-demographic (gender, education, employment status, age, income), household characteristics (homeownership, household size) and dwelling characteristics (type of home, primary heating fuel, presence of specific electric appliances, type of electricity meter). In addition, it controls for relevant socio-psychological variables (pro-environmental orientation, interpersonal trust and feelings of justice).

The results show that electricity consumption is positively related with cooperative membership, suggesting that the cooperative attracts people with a higher electricity use, on average. The magnitude of this effect decreases when controlling for the presence of PV panels, although it remains statistically significant. We argue that this can be explained by a selection process: high use consumers are more likely to install PV panels, hence approach organizations such as cooperatives, which provide active support for installing such technologies and implementing energy efficiency measures.

The following sections of this article present the theoretical considerations motivating this investigation (Section 2), the methodology used (Section 3), the empirical analysis (Section 4), the discussion of the results and some recommendations (Section 5) for future research.

\section{Related work}

The standard theory of collective action assumes that economic agents are self-regarding, i.e. merely caring about their own consumption of public goods (Bowles, 2006). Without coercive measures, this would result in a generalized free-riding behavior and a systematic underprovision of public goods. In the context of electricity use, this assumption leads to the view that individuals will fail to reduce electricity use to the socially efficient level because the costs are paid by the individual 
but the social benefits of energy reduction accrue to everyone' (Ohler and Billger 2014: 1). Behavioral economics provides an alternative approach as to why and when individuals make private provision of public goods. In this vision, individuals also appear to have 'social' preferences (Fehr and Fischbacher, 2002), which can be 'other-regarding' or 'process-regarding' (Ben-Ner and Putterman, 1999). That is to say, rather than strictly about their own, people care about the contribution and consumption of others (other-regarding preferences), and about the ways in which they or others attain outcomes of interest (process-regarding preferences). These other- and process-regarding components explain why individuals accept to follow norms of behavior backed up by emotions such as pride, guilt, shame and anger (Bowles and Gintis, 2009). Social norms are 'customary rules of behavior that coordinate our interactions with others. Once a particular way of doing things becomes established as a rule, it continues in force because we prefer to conform to the rule given the expectation that others are going to conform' (Young, 2008, p. 647). Accordingly, not everyone behaves as a selfish free rider. Instead, many people are better described as 'conditional cooperators', i.e. they will contribute to the public good provided they are sure that others will act likewise and possibly punish defectors. In this perspective, several attempts have been made to formalize the roles of social approval (Rege, 2004) and the maintenance of a satisfactory moral image for others and for self (Brekke et al., 2003; Nyborg et al., 2006) as motivations to adopt cooperative behavior in general and pro-environmental behavior in particular.

Having said this, the extent to which norms are created and enforced is mediated by the specific institutional settings in which social interactions take place. Generally defined, institutions refer to 'the prescriptions that humans use to organize all forms of repetitive and structured interactions including those within families, neighborhoods, markets, firms, sports leagues, churches, private associations, and governments at all scales' (Ostrom, 2005: 3). They constrain the strategies adopted by individuals, the information they access, the benefits they receive or are excluded from and how they reason about the situation. From an institutional viewpoint, a 'community' is characterized by high entry and exit costs and personal relationships among members (Bowles and Gintis, 1998, 
2002). In addition, interactions among community members are more frequent and enduring than interactions with non-members. These structural characteristics of interactions differ from those of other institutions, such as markets, at least where they approximate the ideal completecontracting of standard economic models. Market interactions are typically ephemeral and anonymous, and characterized by low entry and exit costs. 'In contrast to markets, by facilitating direct personal interactions, communities effectively encourage the formation of norms, such as interpersonal trust, social identification, solidarity, reciprocity, reputation, personal pride, vengeance, etc.' (Bauwens 2016: 280).

Relying on these structural characteristics of communities, different qualitative studies suggest that some communities encourage low-carbon lifestyles by stressing the associated social rewards for climate actions (Middlemiss 2008) or by turning the social dilemma they represent into assurance games where members can be assured that others will participate (Heiskanen et al. 2010). Moreover, $\mathrm{CBE}$ initiatives are said to lower information costs related with energy-efficiency technologies and conservation behaviors and therefore contribute to overcome some of the informational and behavioral barriers to energy efficiency constituting the so-called 'energy efficiency gap' (Gillingham and Palmer, 2014). ${ }^{2}$ Indeed, CBE projects may raise their members' awareness about sustainable energy practices through communication channels and information provision. Again, norms are likely to play a role in this respect as the trustworthiness of the sources of information can positively affect the effectiveness of a message (Laskey and Syler, 2013; Stern et al., 1986). Yet, these studies are usually unspecific about the behaviors considered, looking for example at 'lifestyles' or 'social change' and do not evaluate to which extent these behaviors are actually affected.

In addition, recent work has explored the characteristics of members of CBE initiatives and the factors that influence participation in CBE projects. Bamberg et al. (2015) and Kalkbrenner and

\footnotetext{
2 The energy efficiency gap describes the existence of unexploited 'profitable' investment options in energy saving technologies and practices.
} 
Roosen (2016) analyze the predictors of the intention to participate in CBE projects in Germany. Both studies highlight the important role played by community identity in predicting participation intentions. The latter study also emphasizes interpersonal trust and environmental concern as additional driving factors to join CBE initiatives. Radtke (2014) examines the characteristics of a sample of members of CBE initiatives in Germany and shows that participants are not exclusively profit-orientated, tend to be well-educated and to enjoy a good income. Fraune (2015) also analyzes a sample of German CBE initiatives from a gender perspective and finds gender differences in terms of average ownership rates, amount of investment and leadership positions. Finally, Bauwens (2016) focuses on the case of Flanders and shows that members of CBE organizations should not be considered as one homogeneous group. Several categories of members with different motives and levels of engagement can be distinguished. This heterogeneity is explained by contrasts in terms of institutional settings, spatial patterns and attitudes to the diffusion of institutional innovations.

However, even though these studies may serve as useful starting points, they do not examine the characteristics of members of CBE projects in terms of energy use. Given this research gap, the empirical analysis in this article assesses whether and how members of CBE organizations behave differently in terms of electricity use than individuals who do not belong to any cooperative. The methodology followed is presented below.

\section{Methodology}

\subsection{The cooperative model in sustainable energy}

Renewable energy (RE) cooperatives are organizations that enable consumers themselves to coown and invest in sustainable energy projects, such as RE generation or energy efficiency. From an economic standpoint, cooperatives present a different model of ownership from conventional business organizations (Hansmann, 1996). Unlike capitalist corporations, they are owned by their members/users rather than investors, at least when they supply energy. In addition, net earnings 
are usually divided pro rata among the members according to the volume of transactions conducted with the firm. When part of the net income is allocated as a return on share capital, such profit distribution is subject to a cap, which means that maximization of return on capital may not be a key objective. Finally, they use a democratic governance structure, which involves equal individual voting rights and low barriers to entry for new members.

The importance of RE cooperatives varies substantially across Europe. While this model is widespread in some countries, such as Germany and Denmark, its development remains limited in others, e.g. the UK (Bauwens et al. 2016). In Belgium, the cooperative energy sector represents a small share of renewable installed capacity. Yet, among the projects, there are pioneers, such as Ecopower, which is one of the largest cooperatives in Europe in terms of number of members and has been instrumental in the creation of a federation of RE cooperatives at the European level, 'REScoop.eu'.

\subsection{Field setting}

The research question of this article is addressed through case study research on one renewable energy cooperative based in Flanders (the northern part of Belgium), Ecopower. There are currently 6 RE cooperatives in Flanders. However, many of them have been created recently and do not have many members yet. In contrast, Ecopower is relatively well-established, as it is the oldest initiative. In 2013, Ecopower represented 83\% of members of RE cooperatives in Flanders. Hence, the case of Ecopower represents a large majority of members of such organizations in this region.

The cooperative studied here develops renewable energy projects (mostly from wind power, but also solar, biomass and wood pellets) and supplies electricity to its members. It is controlled by individual members who each have equal voting rights and receive a limited return on investments in accordance with the cooperative principles. Table 1 presents some of its basic organizational characteristics. 
Table 1. General characteristics of the cooperative Ecopower.

Year of creation

Number of full-time equivalent workers

Number of members

Price of one cooperative (in euro)

Total cooperative capital (in euro)
1991

22

$48,328,750$

Source: created by author based on 2013 data provided by the cooperative.

Ecopower seeks to encourage energy efficiency and conservation behaviors among its members. First of all, it uses its different communication channels to provide its members with regular advice and information about rational energy use, energy-efficient technologies and green construction. This often begins right after people join the organization. For instance, all new members of Ecopower receive a telephone call from the staff asking questions about their electricity consumption. If this is above the norm, people are questioned about their high consumption and given advice. Other communication channels include the organization's quarterly newsletters and website. In addition, the cooperative collaborates with the web platform EnergieID in order to help members modify its energy use. This website enables energy users to compare their electricity consumption with other similar households'. Ecopower promotes this website among its members and a more formal partnership was established in 2012 with the creation of an 'Ecopower' group on the website. Those joining this group are invited to report their electricity consumption monthly. The cooperative can then analyze these consumption figures and provide members with a personalized report about their consumption and how to reduce it further.

Interestingly, Ecopower does not charge any fixed fee for electricity connection and only charges what is actually consumed. This is a strong incentive to join the cooperative for people who generate their own electricity. On the other hand, it actively encourages its members to install PV panels on their rooftop. For instance, in 2007, jointly with another RE cooperative, it set up a project to install and/or provide technical assistance in installing PV panels on its members' roof. 
Members had two options: getting the cooperative to install solar panels for them in exchange of a renting fee or installing them with their own capital. In the latter case, the cooperative recommended the installation company and the most suitable technological option (in terms of price and quality).

\subsection{Data collection}

We collected household data on cooperative members through an online questionnaire-based survey conducted between May and June 2014. The design of the questionnaire was based on a qualitative exploratory data collected through several non-structured interviews with managers, workers and members of the cooperative, with the purpose of understanding better the issues at play and discovering important underlying factors that might be missed. The cooperative provided members' email addresses. 36,642 emails were sent to Ecopower members. Furthermore, hard copies of the questionnaire were distributed during the organization's General Meeting to the purpose of reaching a profile of people who would not have been reached by the online questionnaire. Indeed, General Meeting participants are typically an older public with a presumably lower usage of the Internet. 195 printed copies of the questionnaire were handed out in Ecopower's General Meeting. All in all, out of the 36,837 copies distributed in total, 3988 respondents participated in the survey. While this $10.8 \%$ response rate averages that obtained in similar surveys (Litvine and Wüstenhagen, 2011), drawing firm conclusions about the generality of members calls for caution.

The distributions of the location of members and of the duration of their membership was known for the whole population of cooperative members. To enhance the representativeness of the collected sample regarding these variables, weighting factors were computed based on these variables and applied in the analysis (Table 2). Weighting factors adjust the sample data so that the joint sample distribution of members' location and duration of membership matches their known 
joint population distribution. Values above 1.00 in Table 2 boost the weight given to the data collected from participants in the relevant group, and vice-versa.

Table 2. Weighting factors used in the data analysis.

\begin{tabular}{lccccc}
\hline Province & \multicolumn{5}{c}{ Duration of membership (in years) } \\
\hline & $0 \leq x<5$ & $5 \leq x<10$ & $10 \leq x<15$ & $15 \leq x<20$ & $20<x$ \\
Antwerpen & 1.053 & 0.852 & 0.726 & 0.015 & 0.114 \\
Brussels & 1.169 & 0.945 & 0.806 & 0.017 & 0.126 \\
Limburg & 1.227 & 0.992 & 0.846 & 0.017 & 0.133 \\
Oost-Vlaanderen & 1.183 & 0.957 & 0.815 & 0.017 & 0.128 \\
Vlaams Brabant & 1.169 & 0.945 & 0.806 & 0.017 & 0.126 \\
West-Vlaanderen & 1.068 & 0.863 & 0.736 & 0.015 & 0.115 \\
Other & 1.375 & 1.112 & 0.948 & 0.020 & 0.149 \\
\hline
\end{tabular}

Source: survey (2014).

In addition, data were collected for energy users who do not belong to a cooperative $(\mathrm{N}=501)$ in order to compare the results for the two groups. The data collection for this comparison group was carried out by a professional survey institute (IPSOS). Quotas were imposed so that the comparison group had the same characteristics in terms of gender, geographical location and education level as the reference group of cooperative members. Hence, the purpose was not for the comparison group to be representative of the general Flemish population, but instead, to differ as little as possible from the reference group in characteristics other than membership of a RE cooperative. As IPSOS's respondent panel did not contain people aged above sixty-five, the cooperative members above this age were removed from the analysis. Hence, a final total sample of 4,068 observations was used.

\subsection{Variables}

The dependent variable is a binary variable that takes the value 1 if individual $i$ belongs to a cooperative and 0 otherwise. Moreover, respondents were asked to indicate their total household electricity consumption for the year 2013, in kWh, which includes the electricity bought from their electricity supplier and the auto-produced electricity used on site if households have PV panels. Table 3 presents the descriptive statistics for cooperative membership and electricity consumption. 
Table 3. Descriptive statistics of cooperative membership and electricity consumption.

\begin{tabular}{cllcc}
\hline \multicolumn{1}{c}{ Variable } & \multicolumn{1}{c}{ Description } & N & Mean & SD \\
\hline COOPERATIVE & $=1$ if individual is member of the & & & \\
& cooperative & 4068 & 0.88 & 0.33 \\
CONSUMPTION & Electricity consumption in $\mathrm{kWh}$ & 3681 & 5235.45 & 4702.13 \\
\hline
\end{tabular}

Source: survey (2014).

In addition, data were also collected to control for basic socio-economic variables (gender, education, age, income, employment status), household characteristics (household size, homeownership) and dwelling characteristics (apartment or house, type of electricity metering, presence of particularly high energy-consuming electric appliances: dryer, dish-washer, toaster, electric boiler, kettle, ceramic glass cooktop).

Finally, data were collected for indicators of socio-psychological characteristics, including distributive and procedural feelings of fairness, interpersonal trust and pro-environmental orientation. As regards individuals' procedural and distributive feelings of fairness, judgements about justice related to society considered globally ${ }^{3}$ were accessed by adapting items used in organizational psychology (Colquitt, 2001) and in a survey about representations of social justice (Jacquemain, 1995). They were answered through 5-point Likert scales, from $1=$ 'completely disagree' to $5=$ 'completely agree'. Interpersonal trust, i.e. the extent to which people trust others in general, was measured using three items adapted from the World Value Survey. More specifically, respondents had to answer on 7-point scales the following questions: 'In general, do you think that most people can be trusted, or that you cannot be too careful in dealing with other people?', 'Do you think most people are helpful, or that most people are selfish?' and 'Do you think that most people try to take advantage of you, or that most people try to be fair?'. In addition, data were collected for respondents' so-called 'pro-environmental orientation', which was captured through

\footnotetext{
${ }^{3}$ Questions related with procedural and distributive justice were purposefully not about cooperative management of wind energy projects, given the obvious bias that cooperative members' answers would contain. Hence, in order to be able to contrast the group of cooperative members to the comparison group, it was decided to measure perceptions of justice at a more fundamental level.
} 
two dimensions: pro-environmental self-identity and daily behaviors. The degree of proenvironmental self-identity was measured through six items selected and adapted from existing questionnaires (Castro et al., 2009; Fielding et al., 2008; Whitmarsh and O’Neill, 2010). These items measure the extent to which the respondent perceives himself as someone concerned with the environment. Respondents' pro-environmental engagement in terms of daily behaviors was measured using pro-environmental behaviors selected from an existing study (Delacolette et al., 2011), such as 'reuse old plastic bags' or 'buy fruit and vegetables grown locally rather than imported'. Respondents were asked to indicate the frequency at which they executed each of the five actions over the last fortnight. The items for all socio-psychological characteristics were then aggregated into single indices. Table 4 reports the specific statements along with statistics to test for internal consistency (item-total correlations and Cronbach's alpha ${ }^{4}$ ). To facilitate interpretation, indicators of socio-psychological characteristic were transformed into binary variables taking the value 1 if the respondent's score is above the median and 0 otherwise.

Table 4. Item-total correlation and Cronbach's alpha for the different scales.

\begin{tabular}{|c|c|}
\hline & $\begin{array}{l}\text { Item-total } \\
\text { correlation } \\
\text { and } \\
\text { Cronbach's } \\
\text { alpha } \\
\end{array}$ \\
\hline \multicolumn{2}{|l|}{ Pro-environmental orientation } \\
\hline 1. I feel concerned about climate change. & 0.46 \\
\hline 2. I think that human activities are one of the main causes of climate change. & 0.45 \\
\hline 3. I am the type of person who cares about ecology. & 0.49 \\
\hline 4. I think of myself as an eco-responsible consumer. & 0.40 \\
\hline 5. I want to feel that I personally contribute to the protection of the environment. & 0.40 \\
\hline $\begin{array}{l}\text { 6. I like that my family or my friends think of me as someone concerned about the } \\
\text { environment }\end{array}$ & 0.63 \\
\hline 7. Travel short distances on foot or by bike & 0.45 \\
\hline 8. Avoid plastic bags in shops & 0.65 \\
\hline 9. Reuse old plastic bags & 0.68 \\
\hline 10. Buy fruit and vegetables grown locally rather than imported & 0.67 \\
\hline 11. Turn off the tap while brushing my teeth & 0.57 \\
\hline Cronbach's alpha & 0.84 \\
\hline
\end{tabular}

\footnotetext{
${ }^{4}$ Cronbach's alpha is a statistic that provides a measure of the internal consistency of a test or scale, i.e. the extent to which all the items in a test measure the same concept or construct; it is expressed as a number between 0 and 1 . A low alpha may be due to poor interrelatedness between items. Conversely, if alpha is too high, it may suggest that some items are redundant. Values ranging from 0.70 to 0.95 are considered acceptable in most social science research situations (DeVellis, 2003; Nunnally and Bernstein, 1994).
} 


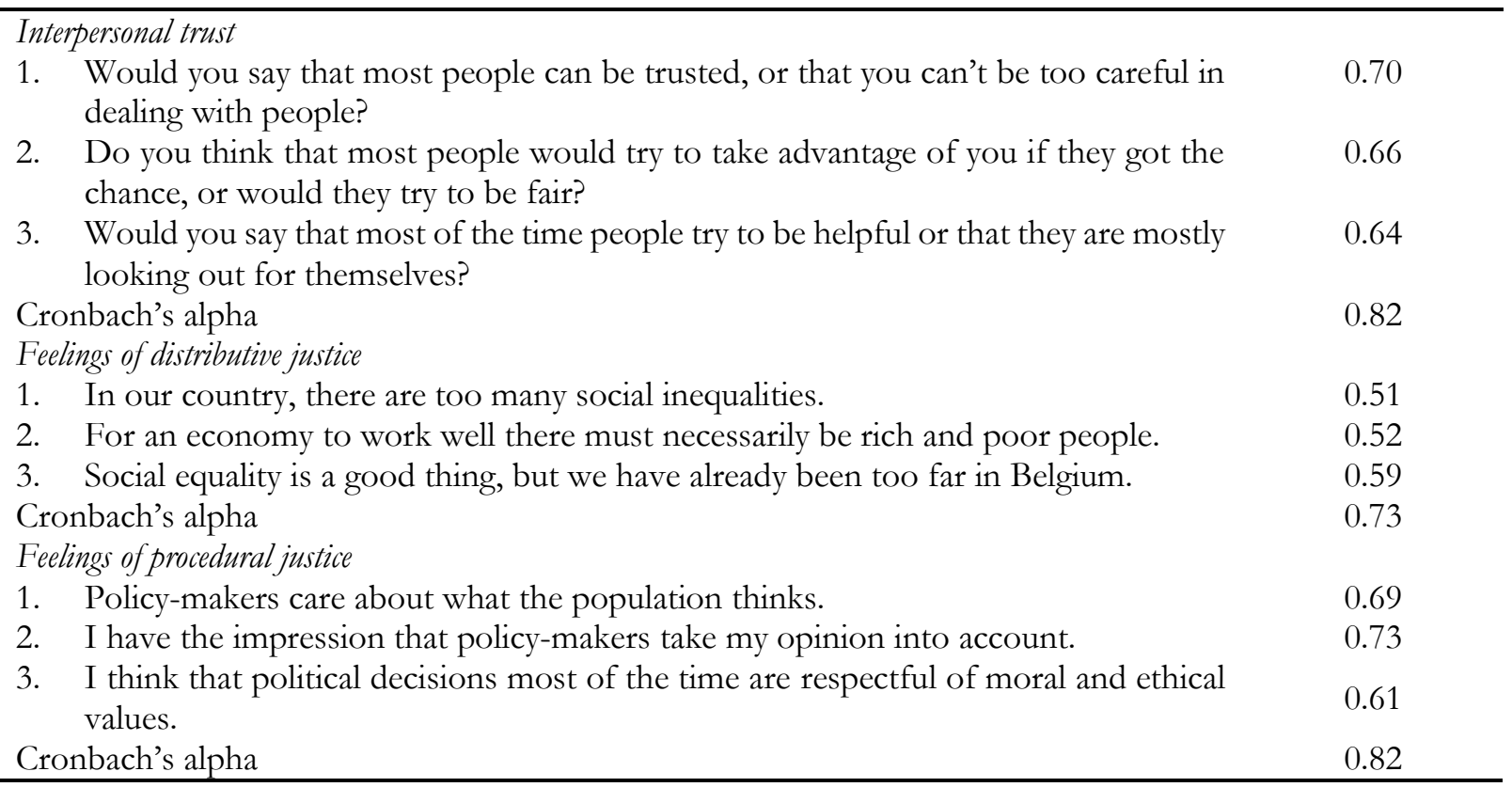

Source: created by authors.

Tables 5 and 6 present the description and summary statistics of the household, dwelling, socio-

demographic and socio-psychological variables used in the analysis.

Table 5. Descriptive statistics of the dwelling variables.

\begin{tabular}{llcrc}
\hline \multicolumn{1}{c}{ Variable } & \multicolumn{1}{c}{ Description } & N & Mean & SD \\
\hline APARTMENT & $=1$ if household lives in an apartment & 4007 & 0.10 & 0.29 \\
HOUSE & $=1$ if household lives in a house & 4007 & 0.90 & 0.30 \\
FUEL & $=1$ if primary heating system based on fuel & 4067 & 0.18 & 0.38 \\
ELECTRICITY & $=1$ if primary heating system based on electricity & 4067 & 0.02 & 0.16 \\
NATURAL & $=1$ if primary heating system based on natural gas & 4067 & 0.66 & 0.47 \\
WOOD & $=1$ if primary heating system based on wood & 4067 & 0.05 & 0.22 \\
PELLETS & $=1$ if primary heating system based on pellets & 4067 & 0.03 & 0.17 \\
HEATPUMP & $=1$ if primary heating system based on heat pump & 4067 & 0.04 & 0.20 \\
HEATOTHER & $=1$ if primary heating system based on other fuel & 4067 & 0.01 & 0.11 \\
DISHWASH & $=1$ if presence of a dish-washer in the home & 4013 & 0.78 & 0.42 \\
WASHING & $=1$ if presence of a washing-machine in the home & 4059 & 0.97 & 0.17 \\
DRYER & $=1$ if presence of a dryer in the house in the & & & \\
& home & 3930 & 0.72 & 0.45 \\
TOASTER & $=1$ if presence of a toaster in the home & 3948 & 0.81 & 0.39 \\
KETTLE & $=1$ if presence of a kettle in the home & 0.79 & 0.41 \\
CERAMIC & $=1$ if presence of ceramic glass cooktops in the & & & \\
& home & 3716 & 0.50 & 0.50 \\
BOILER & $=1$ if presence of an electric boiler in the home & 3645 & 0.31 & 0.46 \\
SINGLEMETER & $=1$ if the home has a single rate meter & 4003 & 0.34 & 0.47 \\
TWOMETER & $=1$ if the home has a two rate meter & 4003 & 0.66 & 0.47 \\
\hline
\end{tabular}

Source: survey (2014). 
Table 6. Descriptive statistics of the household, socio-demographic and socio-psychological variables.

\begin{tabular}{|c|c|c|c|c|}
\hline Variable & Description & $\mathbf{N}$ & Mean & SD \\
\hline \multicolumn{5}{|l|}{ Household variables } \\
\hline HOUSESIZE & Number of residents in the household & 3936 & 3.00 & 1.58 \\
\hline OWNER & $=1$ if household is owner of the home & 4055 & 0.92 & 0.27 \\
\hline TENANT & $=1$ if household rents the home & 4055 & 0.08 & 0.27 \\
\hline \multicolumn{5}{|c|}{ Socio-demographic variables } \\
\hline EDUCATION & $\begin{array}{l}\text { Ordinal variable taking the value } 1 \text { if the respondent's } \\
\text { educational attainment is secondary education, } 2 \text { if it } \\
\text { is superior non-university education and } 3 \text { if it is } \\
\text { university education }\end{array}$ & 3929 & 2.08 & 0.76 \\
\hline AGE & Age in years & 4068 & 46.75 & 10.15 \\
\hline GENDER & $=1$ if individual is a man & 4055 & 0.81 & 0.39 \\
\hline INCOME & $\begin{array}{l}\text { Ordinal variable taking the value } 1 \text { if household } \\
\text { income }<2000 € / \text { month, } 2 \text { if } 2000<\text { household } \\
\text { income }<€ 4000 / \text { month and } 3 \text { if household income } \\
>€ 4000 / \text { month }\end{array}$ & 3475 & 2.08 & 0.67 \\
\hline PVPANELS & $=1$ if presence of solar panels & 3956 & 0.48 & 0.50 \\
\hline PROFESSIONAL & $=1$ if the respondent is a professional & 3902 & 0.03 & 0.17 \\
\hline SELF & $=1$ if the respondent is self-employed & 3902 & 0.05 & 0.21 \\
\hline WORKER & $=1$ if the respondent is a worker & 3902 & 0.07 & 0.26 \\
\hline EMPLOYEE & $=1$ if the respondent is an employee & 3902 & 0.43 & 0.50 \\
\hline EXECUTIVE & $=1$ if the respondent is an executive & 3902 & 0.18 & 0.38 \\
\hline OTHERSTATUS & $\begin{array}{l}=1 \text { if the respondent has another employment } \\
\text { status }\end{array}$ & 3902 & 0.05 & 0.22 \\
\hline INACTIVE & $\begin{array}{l}=1 \text { if the respondent is inactive (student, retired, } \\
\text { etc.) }\end{array}$ & 3902 & 0.19 & 0.39 \\
\hline \multicolumn{5}{|c|}{ Socio-psychological variables } \\
\hline PROENVORIENT & $=1$ if pro-environmental orientation $>$ median & 4068 & 0.48 & 0.50 \\
\hline TRUST & $=1$ if interpersonal trust $>$ median & 4068 & 0.43 & 0.50 \\
\hline DISTRIB & $=1$ if feelings of distributive justice $>$ median & 4068 & 0.43 & 0.50 \\
\hline PROCED & $=1$ if feelings of procedural justice $>$ median & 4068 & 0.49 & 0.50 \\
\hline
\end{tabular}

Source: survey (2014).

\subsection{Econometric approach}

Since the ordinary least squares estimator is not efficient in the case of a binary dependent variable, the probability that an individual is a member of the cooperative is modelled by using a probit model $^{5}$, as follows:

$E\left[C_{i} \mid \ln Q_{i}, X_{i}\right]=\operatorname{Prob}\left(C_{i}=1 \mid \ln Q_{i}, X_{i}\right)=\Phi\left(\beta_{1} \ln Q_{i}+\beta_{2} X_{i}\right)$

\footnotetext{
${ }^{5}$ The empirical results are qualitatively and in most cases quantitatively unchanged if a logit specification is used instead.
} 
where $i$ denotes the individual. $C_{i}$ is a dummy that takes the value 1 if the individual belongs to a cooperative and 0 otherwise, $Q_{i}$ is electricity usage for respondent $i$ and $X_{i}$ is an $n$ length vector of control variables. Following other studies of electricity usage (Brounen et al., 2012; Ohler and Billger, 2014), we control for socio-demographic, household and dwelling characteristics. Additionally, we control for relevant socio-psychological variables. Parameters are estimated by maximum likelihood. The cumulative distribution function, $\Phi$, follows a standard normal distribution. The marginal effect for the natural logarithm of electricity consumption is computed as:

$\frac{\partial E\left[C_{i} \mid \ln Q_{i}, X_{i}\right]}{\partial\left(\ln Q_{i}\right)}=\frac{\partial E\left[C_{i} \mid \ln Q_{i}, X_{i}\right]}{\partial Q_{i} / Q_{i}}=\phi\left(\beta_{1} \ln Q_{i}+\beta_{2} X_{i}\right) \beta_{1}$

Where $\phi$ is the standard normal density. The derivative $\frac{\partial E\left[C_{i} \mid \ln Q_{i}, X_{i}\right]}{\partial Q_{i} / Q_{i}}$ is a semi-elasticity and the marginal effect can thus be interpreted as the absolute change in the conditional probability Prob $\left(C_{i}=1 \mid \ln Q_{i}, X_{i}\right)$ associated with one percent change in $Q_{i}$

\section{Results}

\subsection{Mean comparisons}

Table 7 compares the mean scores of electricity consumption, the presence of PV panels and selected socio-demographic, socio-psychological and dwelling characteristics between the group of cooperative members and the comparison group.

Table 7. Comparison of cooperative members to the comparison group.

\begin{tabular}{lccc}
\hline \multicolumn{1}{c}{ Variable } & $\begin{array}{c}\text { Cooperative } \\
\text { members }\end{array}$ & $\begin{array}{c}\text { Comparison } \\
\text { group }\end{array}$ & $\begin{array}{c}\text { Test- } \\
\text { Statistic } \\
\text { s }\end{array}$ \\
\cline { 1 - 3 } CONSUMPTION (in kWh) & Mean (standard error) & Mean (standard error) & \\
\cline { 2 - 3 } PVPANELS & $5460.05(88.45)$ & $3811.44(151.47)$ & $9.40^{* * *}$ \\
PROENVORIENT & $0.52(0.01)$ & $0.19(0.02)$ & $15.95^{* * *}$ \\
TRUST & $0.51(0.01)$ & $0.28(0.02)$ & $10.33^{* * *}$ \\
DISTRIB & $0.47(0.01)$ & $0.21(0.02)$ & $12.26^{* * *}$ \\
\hline
\end{tabular}




\begin{tabular}{lccc}
\hline PROCED & $0.48(0.01)$ & $0.50(0.02)$ & -0.82 \\
EDUCATION & & & \\
$\quad<$ or = High school & $0.25(0.01)$ & $0.25(0.02)$ & 0.09 \\
$\quad$ Superior non-university education & $0.41(0.01)$ & $0.42(0.02)$ & -0.27 \\
$\quad$ University education & $0.34(0.01)$ & $0.33(0.02)$ & 0.18 \\
AGE & $46.79(0.17)$ & $46.54(0.50)$ & 0.34 \\
GENDER & $0.81(0.01)$ & $0.81(0.02)$ & 0.01 \\
INCOME & & & \\
$\quad<€ 2,000 /$ month & $0.18(0.01)$ & $0.21(0.02)$ & -1.13 \\
€2,000<<€4,000/month & $0.55(0.01)$ & $0.54(0.02)$ & 0.10 \\
$\quad$ > 4,000/month & $0.27(0.01)$ & $0.25(0.02)$ & 0.78 \\
SINGLEMETER & $0.70(0.01)$ & $0.35(0.02)$ & $-13.72^{* * *}$ \\
\hline
\end{tabular}

Source: survey (2014). Note: standard errors are in parentheses. Two-samples t-tests were performed to compare the means between both groups. P-value: ${ }^{* * *} \mathrm{p}<.01$.

As regards electricity consumption, interestingly, cooperative members on average use a significantly higher amount of electricity as compared to individuals who do not belong to any RE cooperative. There is also a significantly higher proportion of individuals with PV panels in the sample of cooperative members (52\%) than in the comparison group (19\%). This finding confirms that the cooperative attracts individuals who have installed PV panels on their rooftop and would like to take advantage of the absence of fixed fee for electricity connection (see Section 3.2), and/or individuals who would like to install PV panels, knowing that they would enjoy the support of the cooperative.

Regarding socio-demographic characteristics, the sample of cooperative members is predominantly male $(81 \%)$. This contrasts with the general Flemish population, which is about $49 \%$ male. This gender imbalance is consistent with the results of other studies which show a majority of male participants to community-based initiatives in RE production (Fraune, 2015; Radtke, 2014). Cooperative members are also more educated than the general population. $75 \%$ of cooperative members possess a higher education degree while the proportion of the Belgian population with higher education was 29\% in 2014 (Service Public Fédéral Économie 2014). Furthermore, 27\% of cooperative members have a monthly net household income above $€ 4,000$. These results indicate that the majority of participants are middle-aged, well-educated and mostly well-off. Cooperative 
members, on average, are also significantly more pro-environmentally oriented, have a significantly higher level of interpersonal trust and a significantly lower level of distributive feelings of justice. The difference between both groups in terms of feelings of procedural justice is insignificant. Interestingly, a significantly higher proportion of cooperative members use a 'single rate' meter while a higher proportion of individuals in the comparison group use 'two rate' meters, which makes it possible to track day and night use of electricity separately so that a different $\mathrm{kWh}$ rate can be offered. This can be explained by the fact that Ecopower offers one single electricity tariff which does not change with the time of consumption and is therefore particularly attractive for households with a single rate meter.

\subsection{Correlation analysis}

The Correlation Matrix in Table 8 provides some insights into how independent variables are related to COOPERATIVE and to each other. The highest (positive) correlation with COOPERATIVE is for SINGLEMETER $(r=0.24)$ and PVPANELS $(r=0.22)$. LNCONS, i.e. the logarithm of electricity consumption, is also positively correlated at 0.17 . Homeownership, income and education are significantly positively related with cooperative membership. In addition, the analysis provides coherent evidence on the predictors of energy use: the presence of large electric appliances (dish-washer, washing-machine, dryer, electric boiler) is positively related with electricity consumption, as does the number of residents in the house. The presence of PV panels has the strongest relationship with LNCONS $(r=0.48)$, suggesting that people who have PV panels tend to consume more electricity, on average. People with heat pumps as primary heating fuels also tend to consume significantly more electricity. Moreover, homeownership and the level of income correlate positively with electricity usage. In contrast, people living in apartments rather than houses and people with a high pro-environmental orientation, on average, have a lower electricity use. The latter finding is consistent with the results of several studies which find that environmental 
concern encourages energy saving behaviors (Brandon and Lewis, 1999; Ek and Söderholm, 2008;

Lindén et al., 2006; Sardianou, 2007; Wicker and Becken, 2013). 
Table 8. Correlation matrix.

\begin{tabular}{|c|c|c|c|c|c|c|c|c|c|c|c|c|c|c|c|c|c|c|}
\hline & & 1 & 2 & 3 & 4 & 6 & 7 & 8 & 9 & 10 & 11 & 12 & 13 & 14 & 15 & 16 & 17 & 18 \\
\hline COOPERATIVE & 1 & & & & & & & & & & & & & & & & & \\
\hline LNCONS & 2 & $0.17^{* * *}$ & & & & & & & & & & & & & & & & \\
\hline HOUSESIZE & 3 & $-0.07 * * *$ & $0.23^{* * *}$ & & & & & & & & & & & & & & & \\
\hline APARTMENT & 4 & $-0.14^{* * *}$ & $-0.27^{* * *}$ & $-0.24 * * *$ & & & & & & & & & & & & & & \\
\hline HEATPUMP & 6 & $0.06^{* * *}$ & $0.19 * * *$ & $0.06^{* * *}$ & $-0.05^{* * *}$ & & & & & & & & & & & & & \\
\hline DISHWASHER & 7 & $0.09 * * *$ & $0.27^{* * *}$ & $0.22^{* * *}$ & $-0.21 * * *$ & $0.07^{* * *}$ & & & & & & & & & & & & \\
\hline WASHING & 8 & $0.05^{* * *}$ & $0.16^{* * *}$ & $0.15^{* * *}$ & $-0.23^{* * *}$ & 0.02 & $0.16^{* * *}$ & & & & & & & & & & & \\
\hline DRYER & 9 & $-0.04 * *$ & $0.24^{* * *}$ & $0.20^{* * *}$ & $-0.18^{* * *}$ & $0.03^{* *}$ & $0.32 * * *$ & $0.27 * * *$ & & & & & & & & & & \\
\hline BOILER & 10 & $-0.11^{* * *}$ & $0.09 * * *$ & 0.01 & $-0.03^{*}$ & $0.08^{* * *}$ & -0.01 & -0.01 & 0.04 & & & & & & & & & \\
\hline SINGLEMETER & 11 & $0.24 * * *$ & $0.08^{* * *}$ & $-0.05^{* * *}$ & $-0.05^{* * *}$ & $0.05^{* * *}$ & -0.02 & 0.02 & 0.01 & $-0.07 * * *$ & & & & & & & & \\
\hline OWNER & 12 & $0.19^{* * *}$ & $0.19^{* * *}$ & $0.13^{* * *}$ & $-0.40^{* * *}$ & $0.04^{* * *}$ & $0.24^{* * *}$ & 0.18 & 0.13 & -0.06 & $0.07^{* * *}$ & & & & & & & \\
\hline INCOME & 13 & $0.05^{* * *}$ & $0.23^{* * *}$ & $0.32^{* * *}$ & $-0.18^{* * *}$ & $0.04 * *$ & $0.28 * * *$ & 0.14 & 0.19 & -0.05 & -0.02 & $0.22^{* * *}$ & & & & & & \\
\hline EDUCATION & 14 & $0.07 * * *$ & -0.02 & $0.10^{* * *}$ & 0.01 & 0.02 & $0.12 * * *$ & -0.01 & -0.08 & -0.03 & -0.04 & 0.03 & $0.30^{* * *}$ & & & & & \\
\hline PROENVORIENT & 15 & $0.17^{* * *}$ & $-0.09 * * *$ & $-0.03^{* *}$ & 0.02 & 0.01 & $-0.06 * * *$ & -0.01 & -0.16 & -0.01 & 0.01 & -0.01 & $-0.06 * * *$ & $0.13^{* * *}$ & & & & \\
\hline TRUST & 16 & $0.17^{* * *}$ & -0.01 & 0.02 & $-0.05 * * *$ & 0.01 & $0.04 * *$ & 0.03 & -0.05 & -0.04 & 0.01 & 0.03 & $0.09 * * *$ & $0.14 * * *$ & $0.19 * * *$ & & & \\
\hline DISTRIB & 17 & $-0.14 * * *$ & $0.09 * * *$ & $0.06^{* * *}$ & -0.01 & $0.04 * *$ & $0.10^{* * *}$ & 0.03 & 0.11 & 0.02 & 0.02 & 0.07 & $0.13^{* * *}$ & $-0.04 * *$ & $-0.23^{* * *}$ & $-0.08^{* * *}$ & & \\
\hline PROCED & 18 & -0.01 & $-0.07 * * *$ & $0.05^{* * *}$ & 0.02 & -0.01 & $0.04 * *$ & 0.03 & -0.01 & 0.02 & -0.02 & -0.01 & $0.09 * * *$ & 0.14 & $0.08^{* * *}$ & $0.24 * * *$ & 0.03 & \\
\hline PVPANELS & 19 & $0.22^{* * *}$ & $0.48^{* * *}$ & $0.15^{* * *}$ & $-0.27 * * *$ & $0.13^{* * *}$ & $0.22^{* * *}$ & $0.10^{* * *}$ & $0.16^{* * *}$ & 0.03 & $0.23^{* * *}$ & $0.25^{* * *}$ & $0.18^{* * *}$ & -0.06 & $-0.08 * * *$ & 0.01 & $0.12^{* * *}$ & $-0.05 * * *$ \\
\hline
\end{tabular}

Source: survey (2014). P-value: ${ }^{*} \mathrm{p}<.10 ;{ }^{* *} \mathrm{p}<.05 ;{ }^{* * *} \mathrm{p}<.01$. 


\subsection{Regression analysis}

In this section, cooperative members' actual electricity usage is examined further by simultaneously controlling for factors that are likely to be related with electricity consumption. Table 9 reports the estimation results obtained with the probit estimation. The reported regression coefficients represent the marginal effects of the explanatory variables, which can thus directly be interpreted in terms of change in the probability $\operatorname{Prob}\left(C_{i}=1 \mid \ln Q_{i}, X_{i}\right)$.

Different specifications are estimated and control variables are added gradually. Columns (1) focuses on the bivariate relationship between LNCONS and COOPERATIVE, while column (2) adds the dwelling variables. Column (3) introduces the basic socio-demographic variables, and regression in column (4) includes the socio-psychological variables. Column (5) controls for the presence of PV panels. Finally, column (6) is the richest specification, as it also contains dummies indicating individuals' employment status. Column (7) checks for the robustness of the model with respect to the presence of outliers.

The validity of these results depends on the correct specification of the models. In particular, nonnormality and heteroscedasticity of the residuals lead to inconsistent estimates. Hence, the hypotheses of normality and homoscedasticity of the distribution of the residuals were tested by conducting Lagrange Multiplier tests for homoscedasticity and normality. ${ }^{6}$ The null hypothesis of homoscedasticity cannot be rejected at either the $5 \%$ or the $10 \%$ significance levels in any of the cases. Similarly, the null hypotheses of normality of the distribution cannot be rejected at the $5 \%$ level. These results provide confidence that the likelihood function is correctly specified. In addition, Tukey-Pregibon link specification tests were performed after each regression (Hilbe, 2009). In each case, the link test revealed no problem with our specifications.

\footnotetext{
${ }^{6}$ Both tests are based on the first order conditions from a more general model that specifies the alternative hypothesis, and check whether these are violated.
} 
Regarding the bivariate regression between LNCONS and COOPERATIVE, the relationship is significantly positive, as column (1) shows, with a marginal effect of 0.05 . This suggests that people with higher energy consumption are more likely to join the cooperative, on average.

When controlling for the dwelling variables in column (2), the coefficient of LNCONS remains significantly positive, but decreases to 0.04 . This decrease is driven, in particular, by the inclusion of the variables SINGLEMETER and FLAT, each of which correlates relatively strongly and in the same direction with LNCONS and the dependent variable (positively for SINGLEMETER and negatively for FLAT), as shown in Table 8. Column (2) also provides some information about how dwelling characteristics influence the likelihood of joining the cooperative. Living in an apartment rather than in a house has a significantly negative effect, as does the number of residents in the household. Having a dish-washer, a washing-machine or an electric boiler in the house significantly increases the likelihood of joining the cooperative, while the presence of a dryer and the use of electricity as primary heating fuel have a significantly negative effect. The marginal effect of SINGLEMETER is relatively large and significantly positive. This confirms that people who use a single rate meter instead of a double rate meter are more likely to join the cooperative and can be explained by the unique electricity tariff offered by Ecopower.

The addition of basic socio-demographic characteristics in column (3) does not change the previously highlighted findings, but provides some indications about the socio-demographic profile of cooperative members: homeownership increases the likelihood of being a cooperative member, as does the level of education. The coefficient for the level of income does not appear to be significant when controlling for other factors, despite being significantly positively correlated with COOPERATIVE in Table 8.

As shown in column (4), adding socio-psychological variables (pro-environmental orientation, interpersonal trust and feelings of distributive and procedural justice) does not change our previous results in terms of energy use. Interpersonal trust and pro-environmental orientation are significant 
and positively associated with cooperative membership. This indicates that cooperative members have a higher propensity to trust others in general and are more pro-environmentally oriented, on average, than people who do not belong to any RE cooperative. Feelings of distributive and procedural justice are significant and negatively associated with cooperative membership, although the effect for feelings of procedural justice is small. An interpretation of these inverse relationships between feelings of justice and cooperative membership may be that, by engaging in such projects, people with lower feelings of justice seek to take action in favor of a fairer state of the world as far as energy is concerned.

Column (5) controls for the presence of PV panels. The presence of PV panels significantly increases the likelihood of being a member of the cooperative by a relatively large amount. People who install PV panels are thus more likely to join the cooperative. This confirms that the result highlighted in Section 4.1 holds in a multivariate setting. When controlling for this variable, the coefficient of LNCONS is still significantly positive, but its magnitude is further reduced to 0.02 . This is explained by the fact that the presence of PV panels is positively correlated to both LNCONS and the dependent variable. Hence, the effect of LNCONS was overestimated due to the omission of this variable. This result suggests that high use households may be more likely to install PV panels for economic reasons and, subsequently, approach organizations such as cooperatives, which offer active support for the installation of PV systems and attractive electricity tariffs for PV users.

Column (6) controls for employment status. We see that controlling for these variables does not modify the findings. 
Table 8. Likelihood to join the cooperative.

\begin{tabular}{|c|c|c|c|c|c|c|c|}
\hline & (1) & (2) & (3) & (4) & (5) & (6) & (7) \\
\hline & Probit & Probit & Probit & Probit & Probit & Probit & Probit \\
\hline LNCONS & $0.05^{* * *}(0.01)$ & $0.04 * * *(0.01)$ & $0.04 * * *(0.01)$ & $0.04 * * *(0.01)$ & $0.02 * * *(0.01)$ & $0.02 * * *(0.01)$ & $0.01 * * *(0.00)$ \\
\hline HOUSESIZE & & $-0.03 * * *(0.01)$ & $-0.04 * * *(0.01)$ & $-0.03 * * *(0.01)$ & $-0.03 * * *(0.00)$ & $-0.03 * * *(0.00)$ & $-0.02 * * *(0.00)$ \\
\hline APARTMENT & & $-0.11 * * *(0.02)$ & $-0.10 * * *(0.02)$ & $-0.08 * * *(0.02)$ & $-0.06 * * *(0.02)$ & $-0.05 * * *(0.02)$ & $-0.03 * * *(0.01)$ \\
\hline FUEL & & $-0.05(0.06)$ & $-0.05(0.06)$ & $-0.03(0.05)$ & $-0.02(0.05)$ & $-0.03(0.04)$ & $-0.05 *(0.03)$ \\
\hline ELECTRICITY & & $-0.15^{* *}(0.07)$ & $-0.16^{* *}(0.07)$ & $-0.11 * *(0.06)$ & $-0.11 * *(0.06)$ & $-0.11 * *(0.05)$ & $-0.11 * * *(0.03)$ \\
\hline NATURALGAS & & $0.01(0.06)$ & $-0.02(0.06)$ & $-0.01(0.05)$ & $0.00(0.05)$ & $-0.01(0.04)$ & $-0.04(0.03)$ \\
\hline WOOD & & $0.06(0.07)$ & $0.06(0.07)$ & $0.07(0.06)$ & $0.06(0.05)$ & $0.05(0.05)$ & $0.00(0.03)$ \\
\hline PELLETS & & $0.01(0.07)$ & $0.02(0.07)$ & $0.02(0.06)$ & $0.02(0.06)$ & $0.01(0.05)$ & $-0.03(0.03)$ \\
\hline HEATPUMP & & $0.06(0.08)$ & $0.05(0.07)$ & $0.05(0.06)$ & $0.05(0.06)$ & $0.03(0.05)$ & $-0.02(0.03)$ \\
\hline DISHWASHER & & $0.06^{* * *}(0.02)$ & $0.04 * * *(0.02)$ & $0.04 * * *(0.01)$ & $0.03^{* *}(0.01)$ & $0.03 * *(0.01)$ & $0.03 * * *(0.01)$ \\
\hline WASHING & & $0.07 * *(0.03)$ & $0.08^{* *}(0.04)$ & $0.05(0.03)$ & $0.05 *(0.03)$ & $0.05^{*}(0.03)$ & $0.04 * * *(0.01)$ \\
\hline DRYER & & $-0.07 * * *(0.02)$ & $-0.07 * * *(0.02)$ & $-0.05^{* * *}(0.01)$ & $-0.05^{* * *}(0.01)$ & $-0.05^{* * *}(0.01)$ & $-0.03 * * *(0.01)$ \\
\hline TOASTER & & $-0.01(0.02)$ & $-0.01(0.02)$ & $0.00(0.02)$ & $0.00(0.01)$ & $0.00(0.01)$ & $0.00(0.01)$ \\
\hline KETTLE & & $0.02(0.02)$ & $-0.02(0.02)$ & $-0.02(0.01)$ & $-0.03 * *(0.01)$ & $-0.02 *(0.01)$ & $-0.01(0.01)$ \\
\hline CERAMIC & & $-0.02(0.01)$ & $-0.02(0.01)$ & $0.01(0.01)$ & $0.00(0.01)$ & $0.00(0.01)$ & $0.00(0.01)$ \\
\hline BOILER & & $-0.06^{* * *}(0.01)$ & $-0.06 * * *(0.01)$ & $-0.05^{* * *}(0.01)$ & $-0.05^{* * *}(0.01)$ & $-0.04 * * *(0.01)$ & $-0.02 * * *(0.01)$ \\
\hline SINGLEMETER & & $0.14 * * *(0.01)$ & $0.14 * * *(0.01)$ & $0.13^{* * *}(0.01)$ & $0.09 * * *(0.01)$ & $0.09 * * *(0.01)$ & $-0.05^{* * *}(0.01)$ \\
\hline AGE & & & $0.00 * * *(0.00)$ & $0.00 * * *(0.00)$ & $0.00^{* * *}(0.00)$ & $0.00(0.00)$ & $0.00(0.00)$ \\
\hline OWNER & & & $0.09 * * *(0.02)$ & $0.09 * * *(0.02)$ & $0.06^{* * *}(0.02)$ & $0.05^{* * *}(0.02)$ & $0.03 * * *(0.01)$ \\
\hline GENDER & & & $0.02(0.02)$ & $0.03^{* *}(0.01)$ & $0.03 *(0.01)$ & $0.02(0.01)$ & $0.01 *(0.01)$ \\
\hline INCOME & & & $0.01(0.01)$ & $0.01(0.01)$ & $0.01(0.01)$ & $-0.01(0.01)$ & $-0.01 *(0.00)$ \\
\hline EDUCATION & & & $0.03^{* * *}(0.01)$ & $0.01(0.01)$ & $0.01 *(0.01)$ & $0.00(0.01)$ & $0.00(0.00)$ \\
\hline PROENVORIENT & & & & $0.07 * * *(0.01)$ & $0.06^{* * *}(0.01)$ & $0.06^{* * *}(0.01)$ & $0.04 * * *(0.01)$ \\
\hline TRUST & & & & $0.08^{* * *}(0.01)$ & $0.07 * * *(0.01)$ & $0.06 * * *(0.01)$ & $0.04 * * *(0.01)$ \\
\hline DISTRIB & & & & $-0.08 * * *(0.01)$ & $-0.08 * * *(0.01)$ & $-0.08 * * *(0.01)$ & $-0.04 * * *(0.01)$ \\
\hline PROCED & & & & $-0.02 *(0.01)$ & $-0.01 * * *(0.01)$ & $-0.01(0.01)$ & $-0.01 *(0.01)$ \\
\hline PVPANELS & & & & & $0.11 * * *(0.01)$ & $0.10 * * *(0.01)$ & $0.06^{* * *}(0.01)$ \\
\hline Dummies for employment status & & & & & & YES & YES \\
\hline $\mathbf{N}$ & 2,549 & 2,549 & 2,549 & 2,549 & 2,549 & 2549 & 2,357 \\
\hline Log likelihood & -1011.27 & -852.93 & -821.98 & -745.24 & -709.85 & -678.49 & -467.68 \\
\hline Mc-Fadden's pseudo R-squared & 0.026 & 0.188 & 0.208 & 0.282 & 0.316 & 0.346 & 0.490 \\
\hline
\end{tabular}


One issue that might arise with survey data is measurement error (Bound et al., 2001), which can be the cause of the presence of outliers. ${ }^{7}$ The maximum likelihood method is very sensitive to the presence of outliers and influential observations. This, in turn, can distort parameters estimation. Table 9 reports the summary statistics of the deviance residuals, a diagnostic measure used to detect potential outliers, and the general rule of thumb used to identify potentially problematic observations.

Table 9. Summary statistics for the deviance residuals.

\begin{tabular}{lcccccc}
\hline & $\boldsymbol{N}$ & Mean & $\begin{array}{c}\text { Standard } \\
\text { deviation }\end{array}$ & Min & Max & Criterion \\
\hline $\begin{array}{l}\text { Deviance residuals } \\
\text { (absolute value) }\end{array}$ & 2470 & 0.52 & 0.53 & 0.00 & 3.56 & $>2$ \\
\hline Source $:$ surve (2014) & & & & & &
\end{tabular}

Source : survey (2014).

This table suggests that there is at least one observation that is larger than the typical threshold. Hence, Column (7) presents the probit regression without the observations for which the deviance residual is larger than 2 to see how much impact they have on our regression coefficient estimates. The effect of LNCONS is further reduced to 0.01 , but is still significantly positive.

Finally, when considering separately the people who do not have PV panels and those who do (Table 10), we can see that the effect of LNCONS is still significantly positive for individuals who do not have PV panels. This indicates that people with higher electricity consumption are more likely to join the cooperative, on average, even when they do not own PV panels. The effect is also positive, although insignificant, when restricting the sample to individuals who have PV panels.

Table 10. Likelihood to join the cooperative for the sub-samples of individuals with and without PV panels.

\begin{tabular}{lcc}
\hline & Individuals without PV panels & Individuals with PV panels \\
\hline & Probit & Probit \\
\cline { 2 - 3 } LNCONS & $0.03^{* * *}(0.01)$ & $0.01(0.01)$ \\
HOUSESIZE & $-0.07^{* * *}((0.01)$ & $-0.01^{* * *}(0.00)$ \\
APARTMENT & $-0.12^{* * *}(0.03)$ & $0.00(0.03)$ \\
\hline
\end{tabular}

\footnotetext{
${ }^{7}$ Outliers are observations with large residual, i.e. their dependent-variable value is unusual given their values on the predictor variables.
} 


\begin{tabular}{|c|c|c|}
\hline FUEL & $-0.12(0.10)$ & $0.03(0.03)$ \\
\hline ELECTRICITY & $-0.19 *(0.11)$ & $-0.03(0.03)$ \\
\hline NATURALGAS & $-0.08(0.09)$ & $0.03(0.03)$ \\
\hline WOOD & $0.04(0.11)$ & $0.05(0.03)$ \\
\hline PELLETS & $-0.02(0.12)$ & $0.02(0.03)$ \\
\hline HEATPUMP & $-0.11(0.12)$ & - \\
\hline DISHWASHER & $0.06^{* *}(0.03)$ & $0.01(0.01)$ \\
\hline WASHING & $0.07(0.06)$ & $0.05(0.03)$ \\
\hline DRYER & $-0.11 * * *(0.07)$ & $-0.01 * *(0.01)$ \\
\hline TOASTER & $0.03(-0.11)$ & $-0.01(0.01)$ \\
\hline KETTLE & $-0.01(0.03)$ & $-0.03(0.01)$ \\
\hline CERAMIC & $0.00(0.02)$ & $0.01(0.01)$ \\
\hline BOILER & $-0.11 * * *(0.03)$ & $0.00(0.01)$ \\
\hline SINGLEMETER & $0.13 * * *(0.02)$ & $0.04 * * *(0.01)$ \\
\hline AGE & $0.00(0.00)$ & $0.00 * * *(0.00)$ \\
\hline OWNER & $0.10^{* * *}(0.03)$ & $0.06(0.05)$ \\
\hline GENDER & $0.01(0.03)$ & $0.02 * * *(0.01)$ \\
\hline INCOME & $-0.02(0.02)$ & $0.00(0.01)$ \\
\hline EDUCATION & $0.02(0.02)$ & $-0.01 *(0.01)$ \\
\hline PROENVORIENT & $0.12^{* * *}(0.02)$ & $0.02 * *(0.01)$ \\
\hline TRUST & $0.12^{* * *}(0.02)$ & $0.02 * *(0.01)$ \\
\hline DISTRIB & $-0.15^{* * *}(0.02)$ & $-0.03 * *(0.01)$ \\
\hline PROCED & $0.00(0.02)$ & $-0.01(0.01)$ \\
\hline Dummies for employment status & YES & YES \\
\hline $\mathbf{N}$ & 1267 & 1122 \\
\hline Log likelihood & -471.98 & -181.74 \\
\hline Mc-Fadden's pseudo R-squared & 0.32 & 0.30 \\
\hline
\end{tabular}

\section{Discussion and conclusion}

Elinor Ostrom and other institutional scholars have shown that the tragedy of the commons is not universally valid (Ostrom, 1990). Under certain conditions and, in particular, given the existence of trust and other social norms between individuals, people are able to cooperate in order to overcome the collective-action problem. This analysis can also be applied to climate change as climate change mitigation is a global public good, and relying on existing trust networks at more local scales may contribute to fostering collaboration for a more sustainable use of energy. With the view of gaining a better understanding of the roles played by these local initiatives, this article addressed the question of the selection into community-based sustainable energy organizations in terms of members' energy use, focusing on the case of a renewable energy cooperative. A probit model was used to examine the decision to join the cooperative. 
Our analytical results show that the relationship between participation in the cooperative and electricity consumption is significantly positive. This indicates that people with higher electricity consumption are more likely to join the cooperative, on average. The magnitude of this relationship decreases when controlling for the presence of PV panels, but remains statistically significant. This suggests that part of the higher amount of electricity consumed is related to the presence of PV panels and can be explained by a selection process. For economic motives, households with a higher level of electricity consumption ex ante are more likely to install PV panels on their rooftop and, for this very reason, more likely to join an organization which offers electricity tariffs that are financially interesting for PV users and provides assistance and advice on installing PV panels (see Section 3.2). The effect of electricity consumption is still significantly positive when restricting the sample to individuals who do not own PV panels, and positive but insignificant when the sample is restricted to those who do. Overall, the results suggest that households having a high electricity consumption and/or willing to install solar panels have higher incentives to join a CBE organization which provides assistance and advice on the adoption of green technologies and energy efficiency measures.

This study also provides interesting information about the socio-demographic and psychological characteristics of members of $\mathrm{CBE}$ projects. Cooperative members are more pro-environmentally oriented, have a higher level of interpersonal trust and lower feelings of procedural and distributive justice than members of the comparison group, on average. As the data presented in this study shows, the membership is also relatively culturally and demographically homogeneous and stems from the upper-middle socio-economic class. One may argue that the relative homogeneity among the membership of community-based organizations makes it more difficult to reap the benefits of economic diversity associated with strong complementarities among differing skills and other inputs, and deprives people of valued forms of diversity (Bowles 2006). Additionally, this homogeneity raises important questions of 'recognitional' justice (i.e. justice conceived in terms of who is given respect and who is and isn't valued; see Walker (2012)). On the other hand, 
homogeneity of preferences and interests facilitates collective action, because people who share important social, cultural or economic characteristics may be more willing to cooperate with each other (Poteete and Ostrom, 2004). Similarly, the literature on cooperatives shows that homogeneous interests decrease the costs of collective decision-making (Hansmann, 1999).

As in any research project, however, the choices made in this study reveal some limitations in our findings, which suggests various avenues for future research. First, we did not address the question of behavioral change, given the observational nature of the data. One first avenue for further research thus would consist in designing an empirical strategy that would make it possible to isolate the causal effects of belonging to a community-based energy initiative on energy use. This would require collecting experimental or quasi-experimental data by randomizing individuals into a $\mathrm{CBE}$ project or by mimicking randomization. Another future empirical application could be to assess the effect of different economic and behavioral interventions on the energy consumption of $\mathrm{CBE}$ members, along the lines of the behavioral intervention programs for energy efficiency run in the United States by the cooperatively-owned utility Connexus Energy and the energy efficiency company Opower (see e.g. Allcott 2011). This would involve making observations before and after the implementation of interventions, both in a group of members that receives the intervention and in a control group of members that does not, the members being randomly assigned to intervention and control groups. The choices made in terms of geographical scope and in our sample frame also imply some caution when generalizing our results. Further research could include the evaluation of cooperative organizations in other geographical contexts and of other types of community-based energy projects.

These results contribute to the literature on community-based energy and on management for environmental sustainability. In addition, gaining a better insight on how members of CBE initiatives actually use energy can help practitioners and decision makers design more effective supporting policies to foster energy savings at the community level. 


\section{Acknowledgments}

We thank the University of Oxford's Lower Carbon Futures Team, Patrick Devine-Wright, Julien Jacqmin and two anonymous reviewers for helpful comments on earlier versions of the paper. We also thank Isabelle Peere for her linguistic revision of the present text.

\section{References}

Allcott, H., 2011. Social norms and energy conservation. J. Public Econ. 95, 1082-1095. doi:10.1016/j.jpubeco.2011.03.003

Bamberg, S., Rees, J., Seebauer, S., 2015. Collective climate action: Determinants of participation intention in community-based pro-environmental initiatives. J. Environ. Psychol. 43, 155165. doi:10.1016/j.jenvp.2015.06.006

Bauwens, T., 2016. Explaining the diversity of motivations behind community renewable energy. Energy Policy 93, 278-290. doi:10.1016/j.enpol.2016.03.017

Bauwens, T., Gotchev, B., Holstenkamp, L., 2016. What drives the development of community energy in Europe? The case of wind power cooperatives. Energy Res. Soc. Sci. 13, 136147. doi:10.1016/j.erss.2015.12.016

Ben-Ner, A., Putterman, L.G., 1999. Economics, Values, and Organization. Cambridge University Press, New York.

Bound, J., Brown, C., Mathiowetz, N., 2001. Measurement error in survey data, in: Heckman, J.J., Leamer, E. (Eds.), Handbook of Econometrics. Elsevier, pp. 3705-3843.

Bowles, S., 2006. Microeconomics: Behavior, Institutions and Evolutions. Princeton University Press, Princeton and Oxford.

Bowles, S., Gintis, H., 2009. Beyond Enlightened Self-Interest: Social Norms, Other-Regarding Preferences, and Cooperative Behavior, in: Levin, S.A. (Ed.), Games, Groups, and the Global Good, Springer Series in Game Theory. Springer Berlin Heidelberg, pp. 57-78.

Bowles, S., Gintis, H., 2002. Social Capital And Community Governance. Econ. J. 112, F419-F436. doi:10.1111/1468-0297.00077

Bowles, S., Gintis, H., 1998. The Moral Economy of Communities: Structured Populations and the Evolution of Pro-Social Norms. Evol. Hum. Behav. 19, 3-25. doi:10.1016/S10905138(98)00015-4

Brandon, G., Lewis, A., 1999. Reducing Household Energy Consumption: a Qualitative and Quantitative Field Study. J. Environ. Psychol. 19, 75-85. doi:10.1006/jevp.1998.0105

Brekke, K.A., Kverndokk, S., Nyborg, K., 2003. An economic model of moral motivation. J. Public Econ. 87, 1967-1983. doi:10.1016/S0047-2727(01)00222-5

Brounen, D., Kok, N., Quigley, J.M., 2012. Residential energy use and conservation: Economics and demographics. Eur. Econ. Rev. 56, 931-945. doi:10.1016/j.euroecorev.2012.02.007

Bulkeley, H., Betsill, M., 2005. Rethinking sustainable cities: multilevel governance and the "urban" politics of climate change. Env. Polit 14, 42-63.

Bulkeley, H., Kern, K., 2006. Local Government and the Governing of Climate Change in Germany and the UK. Urban Stud. 43, 2237-2259. doi:10.1080/00420980600936491

Carattini, S., Baranzini, A., Roca, J., 2015. Unconventional Determinants of Greenhouse Gas Emissions: The role of trust. Environ. Policy Gov. 25, 243-257. doi:10.1002/eet.1685

Castro, P., Garrido, M., Reis, E., Menezes, J., 2009. Ambivalence and conservation behaviour: An exploratory study on the recycling of metal cans. J. Environ. Psychol. 29, 24-33. doi:10.1016/j.jenvp.2008.11.003 
Cole, D.H., 2015. Advantages of a polycentric approach to climate change policy. Nat. Clim Change 5, 114-118. doi:10.1038/nclimate2490

Colquitt, J.A., 2001. On the dimensionality of organizational justice: A construct validation of a measure. J. Appl. Psychol. 86, 386-400. doi:10.1037/0021-9010.86.3.386

Delacolette, N., Claus, B., Verbeek, B., Sohet, X., Warlop, L., Dardenne, B., 2011. Fostering Sustainable Behaviors: Community-Based Social Marketing. Belgian Science Policy, Brussels.

DeVellis, R., 2003. Scale development: theory and applications. Sage, Thousand Okas, CA.

Ek, K., Söderholm, P., 2008. Norms and economic motivation in the Swedish green electricity market. Ecol. Econ. 68, 169-182. doi:10.1016/j.ecolecon.2008.02.013

Fehr, E., Fischbacher, U., 2002. Why Social Preferences Matter - The Impact of Non-selfish Motives on Competition, Cooperation and Incentives. Econ. J. 112, C1-C33. doi:10.1111/1468-0297.00027

Fielding, K.S., McDonald, R., Louis, W.R., 2008. Theory of planned behaviour, identity and intentions to engage in environmental activism. J. Environ. Psychol. 28, 318-326. doi:10.1016/j.jenvp.2008.03.003

Fraune, C., 2015. Gender matters: Women, renewable energy, and citizen participation in Germany. Energy Res. Soc. Sci. 7, 55-65. doi:10.1016/j.erss.2015.02.005

Gillingham, K., Palmer, K., 2014. Bridging the Energy Efficiency Gap: Policy Insights from Economic Theory and Empirical Evidence. Rev. Environ. Econ. Policy 8, 18-38. doi: $10.1093 / \mathrm{reep} / \mathrm{ret} 021$

Hansmann, H., 1999. Cooperative Firms in Theory and Practice. Finish J. Bus. Econ. 48, 387-403.

Hansmann, H., 1996. The ownership of enterprise. The Belknap Press of Harvard University Press.

Hardin, G., 1968. The Tragedy of the Commons. Science 162, 1243-1248. doi: $10.1126 /$ science.162.3859.1243

Heiskanen, E., Johnson, M., Robinson, S., Vadovics, E., Saastamoinen, M., 2010. Low-carbon communities as a context for individual behavioural change. Energy Policy 38, 7586-7595. doi:10.1016/j.enpol.2009.07.002

Hilbe, J.M., 2009. Logistic Regression Models. Chapman \& Hall/CRC Press, Boca Raton, FL.

Jacquemain, M., 1995. Représentations de la justice sociale: l'exemple de la Belgique francophone. Année Sociol. 45, 399-430.

Kalkbrenner, B.J., Roosen, J., 2016. Citizens' willingness to participate in local renewable energy projects: The role of community and trust in Germany. Energy Res. Soc. Sci. 13, 60-70. doi:10.1016/j.erss.2015.12.006

Laskey, A., Syler, B., 2013. The Ultimate Challenge: Getting Consumers Engaged In Energy Efficency, in: Sioshansi, F.P. (Ed.), Energy Efficiency: Towards the End of Demand Growth. Academic Press, Oxford.

Lindén, A.-L., Carlsson-Kanyama, A., Eriksson, B., 2006. Efficient and inefficient aspects of residential energy behaviour: What are the policy instruments for change? Energy Policy 34, 1918-1927. doi:10.1016/j.enpol.2005.01.015

Litvine, D., Wüstenhagen, R., 2011. Helping "light green" consumers walk the talk: Results of a behavioural intervention survey in the Swiss electricity market. Ecol. Econ. 70, 462-474. doi:10.1016/j.ecolecon.2010.10.005

Middlemiss, L., 2011. The Power of Community: How Community-Based Organizations Stimulate Sustainable Lifestyles Among Participants. Soc. Nat. Resour. 24, 1157-1173. doi:10.1080/08941920.2010.518582

Middlemiss, L., 2008. Influencing individual sustainability: a review of the evidence on the role of community-based organisations. Int. J. Environ. Sustain. Dev. 7, 78-93. doi:10.1504/IJESD.2008.017898

Nordhaus, W.D., 1994. Managing the global commons. The economics of climate change. M.I.T. Press, Cambridge, MA. 
Nunnally, J., Bernstein, L., 1994. Psychometric theory. McGraw-Hill Higher, INC, New York.

Nyborg, K., Howarth, R.B., Brekke, K.A., 2006. Green consumers and public policy: On socially contingent moral motivation. Resour. Energy Econ. 28, 351-366. doi:10.1016/j.reseneeco.2006.03.001

Ohler, A.M., Billger, S.M., 2014. Does environmental concern change the tragedy of the commons? Factors affecting energy saving behaviors and electricity usage. Ecol. Econ. 107, 1-12. doi:10.1016/j.ecolecon.2014.07.031

Olson, M., 1965. The Logic of Collective Action: Public Goods and the Theory of Groups, Harvard economic studies. Harvard University Press.

Ostrom, E., 2012. Nested externalities and polycentric institutions: must we wait for global solutions to climate change before taking actions at other scales? Econ. Theory 49, $353-$ 369. doi:10.1007/s00199-010-0558-6

Ostrom, E., 2010. Polycentric systems for coping with collective action and global environmental change. Glob. Environ. Change 20, 550-557. doi:10.1016/j.gloenvcha.2010.07.004

Ostrom, E., 2005. Understanding Institutional Diversity. Princeton University Press, Princeton.

Ostrom, E., 2000. Collective Action and the Evolution of Social Norms. J. Econ. Perspect. 14, 137-158. doi:10.1257/jep.14.3.137

Ostrom, E., 1990. Governing the Commons: The Evolution of Institutions for Collective Action, Political Economy of Institutions and Decisions. Cambridge University Press, Cambridge.

Poteete, A.R., Ostrom, E., 2004. Heterogeneity, Group Size and Collective Action: The Role of Institutions in Forest Management. Dev. Change 35, 435-461. doi:10.1111/j.14677660.2004.00360.x

Radtke, J., 2014. A closer look inside collaborative action: civic engagement and participation in community energy initiatives. People Place Policy 8, 235-248.

Rege, M., 2004. Social Norms and Private Provision of Public Goods. J. Public Econ. Theory 6, 65-77. doi:10.1111/j.1467-9779.2004.00157.x

Sandler, T., 2004. Global Collective Action. Cambridge University Press, Cambridge.

Sardianou, E., 2007. Estimating energy conservation patterns of Greek households. Energy Policy 35, 3778-3791. doi:10.1016/j.enpol.2007.01.020

Service Public Fédéral Économie. 2014. 'Niveau D’instruction - Statistiques \& Analyses - Home'. http://statbel.fgov.be/fr/statistiques/chiffres/travailvie/formation/instruction/.

Seyfang, G., 2010. Community action for sustainable housing: Building a low-carbon future. Energy Policy 38, 7624-7633. doi:10.1016/j.enpol.2009.10.027

Stavins, R.N., 1997. Policy Instruments for Climate Change: How Can National Governments Address a Global Problem? Discuss. Pap. E-96-03.

Stern, N., 2007. The Economics of Climate Change: The Stern Review. Cambridge University Press, Cambridge and New York.

Stern, P.C., Aronson, E., Darley, J.M., Hill, D.H., Hirst, E., Kempton, W., Wilbanks, T.J., 1986. The Effectiveness of Incentives for Residential Energy Conservation. Eval. Rev. 10, $147-$ 176. doi:10.1177/0193841 x8601000201

Walker, G., 2012. Environmental Justice: Concepts, Evidence and Politics. Routledge, Abingdon \& New York.

Walker, G., Devine-Wright, P., 2007. Community renewable energy: what should it mean? Energy Policy 36, 497-500.

Whitmarsh, L., O’Neill, S., 2010. Green identity, green living? The role of pro-environmental selfidentity in determining consistency across diverse pro-environmental behaviours. J. Environ. Psychol. 30, 305-314. doi:10.1016/j.jenvp.2010.01.003

Wicker, P., Becken, S., 2013. Conscientious vs. ambivalent consumers: Do concerns about energy availability and climate change influence consumer behaviour? Ecol. Econ. 88, 41-48. doi:10.1016/j.ecolecon.2013.01.005 
Wiener, J.B., 2007. Think Globally, Act Globally: The Limits of Local Climate Policies. Univ PA Law Rev 155, 1961-1979.

Young, H.P., 2008. social norms, in: Durlauf, S.N., Blume, L.E. (Eds.), The New Palgrave Dictionary of Economics. Palgrave Macmillan, Basingstoke. 